\title{
An Assessment of the Fourche Maline Culture and Its Place in the Prehistory of Northeast Texas
}

Frank Winchell

Unknown

Follow this and additional works at: https://scholarworks.sfasu.edu/ita

Part of the American Material Culture Commons, Archaeological Anthropology Commons, Environmental Studies Commons, Other American Studies Commons, Other Arts and Humanities Commons, Other History of Art, Architecture, and Archaeology Commons, and the United States History Commons

Tell us how this article helped you.

This Article is brought to you for free and open access by the Center for Regional Heritage Research at SFA ScholarWorks. It has been accepted for inclusion in Index of Texas Archaeology: Open Access Gray Literature from the Lone Star State by an authorized editor of SFA ScholarWorks. For more information, please contact cdsscholarworks@sfasu.edu. 


\section{An Assessment of the Fourche Maline Culture and Its Place in the Prehistory of Northeast Texas}

\section{Creative Commons License}

\section{(c) (1) \&}

This work is licensed under a Creative Commons Attribution-NonCommercial 4.0 International License 


\title{
An Assessment of the Fourche Maline Culture and Its Place in the Prehistory of Northeast Texas
}

\author{
Frank Winchell
}

This paper is based on the works of many authors who have investigated and written upon archaeological materials involving pre-Caddo cultures that existed in the Caddo Area, west of the Mississippi River. I will be concentrating on one particular archaeological manifestation known as the Fourche Maline Culture, which existed perhaps as early as 500 B.C. and ended sometime during the 2 nd millenium A.D.

The origins of the Fourche Maline Culture are still not well understood, however, it can be stated with some assurance that it was an in-place development occurring somewhere within the Caddo Area. How far widespread was this culture? Some researchers believe that the Fourche Maline Culture was ubiquitous throughout the Caddo Area in the states of Oklahoma, Arkansas, Louisiana, and Texas (Schambach 1982).

I will be concentrating mainly on the Fourche Maline Culture in Texas, which I believe existed there. The existence of a Fourche Maline Culture in Texas, to me, does not revolve around the argument of whether the Early Ceramic Period of Texas should be called Fourche Maline, or whether the Fourche Maline Culture should be termed Early Ceramic. In either case, equating the two would be wrong. As an alternative explanation, I believe that the Fourche Maline Culture represented a particular Woodland Period (500 B.C.-A.D. 1000) cultural phenomenon within the Early Ceramic Period of Northeast Texas which finally expressed itself as a Middle (O-A.D. 500) to Late (A.D. 500-1000) Woodland Period manifestation known as the Alto Focus. Furthermore, I believe that the Fourche Maline Culture existed beyond the Woodland biome along the prairie margins in Northeast Texas in what has been commonly referred to as the Sanders focus.

Both the Alto and Sanders foci have been traditionally known in Texas as belonging to the Caddo Culture (Krieger 1947; Newell and Krieger 1949; Story 1981). I will argue that both the Alto and Sanders foci can be better understood as late or epi-Fourche Maline cultural manifestations which straddled the Woodland (Fourche Maline) and Mississippian (Caddo) Periods in Northeast Texas. Ultimately, it is from these two foci (the Alto and Sanders) that the full expression of the Caddo Culture was first seen in the state of Texas.

\section{Definition of the Fourche Maline Culture}

The Fourche Maline Culture got its name originally from Fourche Maline Creek of LeFlore County in the northern Ouachita Mountains of Southeast Oklahoma (Newkumet 1940a,b; Bell 1948, 1949, 1953; Bell and Baerreis 1951). There, some 10 or more sites situated along Fourche Maline Creek, Black Fork Creek, and the Poteau River, were found containing considerable amounts of ceramics, firecracked rocks, bone, and lithics (Bell and Baerreis 1951:19-27; Bell 1980:91-96). Many of these sites contained deep, artifact-rich middens which had a characteristic "black colored earth" (Bell and Baerreis 1951; Bell 1980:92). As early as 1947, these particular Fourche Maline "focus" sites were compared, and said to be very much like Sanders Focus sites in Northeast Texas (Krieger 1947:202; Bell 1980:86). In fact, some of the ceramic 
material between the two foci were considered to be identical. However, unlike the Sanders Focus sites of the Caddo Period, the Fourche Maline Focus sites were found to date to the Woodland Period (Bell and Baerreis 1951; Bell 1980).

By the end of the 1950s it was realized that expressions of the Fourche Maline Focus were not restricted to the small drainages associated with the northern Ouachita Mountains, but were more widespread throughout Eastern Oklahoma, including sites and occupations associated with the Spiro Mound site along the Arkansas River. At the same time, it was shown that the Fourche Maline Focus of Eastern Oklahoma had been a direct development out of the local Archaic tradition there, but for many years both nonceramic and ceramic-bearing occupations associated with this focus were lumped together (Wyckoff 1966, 1970; Bell 1980:114-115).

During the 1960s, the Oklahoma Fourche Maline Focus was beginning to be recognized in other areas, particularly along the Red, Little, and Ouachita Rivers in Southwest Arkansas (Wood 1963a,b; Schambach 1970, 1982:141-160, 187). The recognition of Fourche Maline sites was based primarily on the presence of the characteristic thick, usually grog or bone tempered, flat based, flower-pot shaped ceramics called Williams Plain (Newkumet 1940a; Bell and Baerreis 1951; Bell 1953:331; Schambach 1982:160-161). Like the Oklahoma Fourche Maline, the Williams Plain ceramics in Arkansas were associated with characteristic black middens, boatstones, double-bitted axes, groundstome manos and metates, Gary projectile points, and some Hopewellian trade items such as copper, quartz crystals, and large, well-made lithic bifaces, all of which were consistently dating to the Woodland Period (Wood 1963a,b; Schambach 1970, 1982; Hoffman 1971).

Based on the discovery of Fourche Maline sites in Arkansas, it was recognized that the original Fourche Maline complex of Southeast Oklahoma represented a much larger archaeological manifestation which more or less covered the entire Caddo Area (Schambach 1982). Supporting this hypothesis, other Woodland Period occupations in Louisiana such as the Bellevue Focus (Fulton and Webb 1953:18-42) were also beginning to be recognized as having affiliations with Fourche Maline complexes in Oklahoma and Arkansas (Webb and Gregory 1978:2; Schambach 1982:187). As early as 1962, the Fourche Maline Focus had been stated to have been associated with the later part of the La Harpe Aspect, and was recognized at several sites in Northeast Texas along the Upper Sabine Basin and the South Sulphur River (Johnson 1962). However, the idea of a widespread Fourche Maline complex evolving out of an equally large Archaic tradition never really took hold in the archaeology of Texas (Story 1981, 1985).

During the first part of the 1980s published materials on the Fourche Maline cultural manifestation became more formalized (Bell 1980; Schambach 1982). Essentially, what had been termed as the Fourche maline Focus or complex became to be called the Fourche Maline Culture (Schambach 1982). At this time, it was becoming more and more clear that the Fourche Maline Culture was ancestral to the later Caddo Culture, and as a result, the "center of gravity" of the Fourche Maline Culture was shifted from Oklahoma to somewhere in Arkansas, in or near the Great Bend Area of the Red River (Schambach 1982:161, 187, 191).

At the same time, it was recognized that the Fourche Maline Culture represented two major areal divisions, one occurring in the highlands regions (such as the Ouachita Mountains), and the other occurring in the lowland regions and major river valleys of the Caddo Area (Schambach 1970, 1982; Bell 1980:107). The Fourche Maline Culture in Arkansas also was divided into seven periods and regions with associated phases, many 
of which were felt to represent similar developments in other states within the Caddo Area (Schambach 1982:138-141).

Basically, the Fourche Maline Culture was defined in the context of the TransMississippi South (Schambach 1970, 1982:133-137). The Trans-Mississippi South was interpreted as being an ecotonal area west of the Mississippi Valley which was essentially cut off from the Mississippi Valley to the east and the Great Plains to the west (Schambach 1982:133). Climatically, this ecotonal area since the late Holocene was thought to be more arid and experienced erratic amounts of rainfall, which in effect, made the Trans-Mlssissippi South as a whole more unstable for human occupation as opposed to the Lower Mississippi Valley which had a more stable environment with more predictable amounts of rain. Using an ecosystems approach, the essential character of the Fourche Maline Culture was translated through the ecology of the Trans-MIssissippi South (Schambach 1982:136).

Based on this ecosytems approach, it was postulated that the Fourche Maline Culture of the Trans-Mississippi South was culturally distinct from contemporary societies living in the Lower Mississippi Valley (Schambach 1982:136). Knowing that the Fourche Maline Culture had developed from a local Archaic tradition, it was now plausible to argue that the Fourche Maline and Lower Mississippi Valley cultures had emerged as separate cultural entities (Schambach 1982). Previous to this idea, it was believed that most, if not all Woodland Period developments in the Caddo Area were actually westward extensions or expansions of Lower Mississippi Valley cultures (Dickinson 1936:68; Ford 1951:124-125; Hoffman 1970, 1971; Webb and McKinney 1975; Perttula 1980). This was based on the frequent occurrence of Marksville, Troyville, or Coles Creek ceramic types found in association with Fourche Maline or socalled pre-Caddo occupations.

However, it was demonstrated that there were fundamental differences between Fourche Maline type ceramics and contemporary Lower Mississippi Valley types mentioned above. What was realized was that most, if not all, of the diagnostic ceramics recognized as being Marksville, Troyville, or Coles Creek were actually made from local pastes which were entirely different from their Lower Mississippi Valley counterparts (Schambach 1982:164-172). Pastes of Marksville, Troyville, or Coles Creek-like pottery found on Fourche Maline sites were recognized to be consistently coarser than their Lower Mississippi Valley counterparts, and more significantly, the use of crushed bone was liberally used as temper among the Fourche Maline ceramics. In contradistinction to this, bone tempered pastes were never present in the Lower Mississippi Valley, nor was it found anywhere east of the river (Davis 1961:17; Schambach 1982, 1989 personal communication).

Nevertheless, the presence of what appeared to be Marksville or Coles Creek-like ceramic styles definitely attests to horizon style influences which more than likely originated from the Lower Mississippi Valley. The presence of horizon style markers in the Caddo Area certainly would be attributed to forces of stimulus diffusion (e.g., Childe 1942, 1952). However, as opposed to Fourche Maline societies accepting Lower Mississippi Valley pots in toto, it is more likely that Fourche Maline potters were incorporating Lower Mississippi Valley design styles on their pots.

I believe that the Fourche Maline Culture is not strictly an ecologically based phenomenon embedded in the Trans-Mississippi South, but is actually more representative of a particular linguistic group. This argument is based on linguistic and ethnohistoric data which demonstrates that spatially the Fourche Maline Culture covers 
much of the area which was inhabited by the southern Caddoan speakers (see Swanton 1946). Arguably, the Trans-Mississippi South covers much the same area; however, due to its ecotonal nature, which incorporates a number of diverse environmental niches, it cannot explain the widespread distribution of related culture groups which apparently were distributed across many different environmental provinces and plant domains. There is no doubt that different segments of the Fourche Maline Culture utilized their local habitats in different ways which reflected different modes of adaptation. In fact, one of the big differences between the Fourche Maline Culture and its counterparts in the Lower Mississippi Valley is that social groups belonging to the former were much more economically diversified than societies living in the Lower Mississippi Valley, who were more or less restricted to the Mississippi River floodplain. However, through the material culture, specifically the ceramics, it appears that the Fourche Maline Culture was quite unified across a widely diversified environmental area, and I believe the most plausible explanation for this is that societies within the Fourche Maline Culture shared a common language.

It has been pointed out that there was an "ecological boundary between bottomland forest environments of the Lower Mississippi Valley and the upland forest environment of the Trans-Mississippi South" (Schambach 1982:136). At the same time, there probably was a language barrier between Muskhogean and Caddoan speakers along this boundary as well. In the final analysis, environmental boundaries such as the one dividing the Trans-Mississippi South from the Lower Mississippi Valley also demarcated major linguistic zones. If we can make the argument that the Fourche Maline Culture shared a common language, and that the language spoken was probably Caddoan or protoCaddoan, then it serves to reason that the Fourche Maline Culture belongs to the greater Caddoan Culture Tradition. This, of course, seems to be in agreement with the archaeological record.

\section{The Fourche Maline Culture in Texas}

There are a number of Early Ceramic-Woodland Period sites in Northeast Texas which are arguably Fourche Maline in character. Such sites as the Manton Miller Site, along the South Sulphur River in the Cooper Lake area, had in the past been identified as containing a Fourche Maline component with Williams Plain ceramics (Johnson 1962:265-266). However, many other Early Ceramic sites, such as Snipe (in Cass County on the south bank of the Sulphur River), Limerick (in Rains County in the Upper Sabine River Drainage Basin), Resch (in Harrison County in the Sabine River Drainage Basin), and the Sawmill Site (on the Angelina River in San Augustine County), were identified as representing local manifestations which contained Woodland Period Lower Mississippi Valley materials, mixed or associated with some Early Caddo ceramics (Webb et al. 1969; Duffield 1961; Jelks 1961; Tunnell 1961). At the same time, none of these sites were considered by their excavators as being Fourche Maline in nature. However, at the Resch and Snipes sites, many of the thick plain wares, identified as either Tchefuncte or Baytown Plain (Webb et al. 1969:28-43; Jelks 1961:47-48), are probably more akin to Williams Plain. In fact, among the plain wares recovered at these sites, there were significant quantities of bone tempered ceramics, which would in turn signify their affiliation with the Fourche Maline Culture. At the Limerick Site, plain grog and bone tempered ceramics were automatically classified as Sanders Plain (Duffield 1961:88, 99-100, 111), even though it was suspected that the ceramicbearing occupations there were considered to be transitional Late Archaic/Neo-American based on the high proportion of dart points, including late style Gary points (Duffield 1961:63, 65, 109-115). 
I note that the Early Ceramic Period sandy paste wares such as Goose Creek and Bear Creek found on many of the sites discussed above should not be included within the Fourche Maline Culture. When sandy paste wares are found with grog and bone tempered wares in an Early Ceramic Period context, the former paste group usually appears to be earlier (Aten 1983). Furthermore, when sites with sandy paste wares are plotted, the areal distribution corresponds very well to the distribution of Atakapan speakers who inhabited the southern rim of the Gulf Coastal Plain south of the Caddoan speakers (Swanton 1946). This striking dichotomy between sandy paste wares and grog and bone tempered wares seems to reinforce the notion of a strong linguistic correlation between different paste groups, as was present between Muskhogean speakers of the Lower Mississippi Valley and Caddoan speakers of the Trans-Mississippi South. In a recent publication, Story (1990:256-258) also gives credence to making a cultural distinction between Early Ceramic components containing sandy paste wares in southeastern Texas, which she terms the Mossy Grove Culture/Tradition, versus those components farther north (associated with Caddoan groups) which contain grog and bone tempered wares. At the time the author was writing this paper, Dr. Story's publication on the Mossy Grove Tradition was still in press, and he did not have the opportunity to investigate her thoughts on this matter at the time.

Both the Snipe and Resch sites contained significant amounts of Marksville, Troyville, and Coles Creek-like ceramics, and like the plain wares, a significant number of these were tempered with bone. These particular sites also contained a number of Caddo ceramics, most of which could be typed as belonging to the Alto focus (Jelks 1961:51; Webb et al. 1969:39-40). Paste wise, the Caddo ceramics from both sites were not different from the plain wares, nor were they different from the decorated Lower Mississippi Valley style ceramics. At the Resch site, it was demonstrated stratigraphically that the Alto focus ceramics were co-varying with both Marksville and Coles Creek ceramics (Webb et al. 1969:88-90). Likewise, at the Snipe site, where a number of Alto focus ceramic types were apparently associated with Marksville, Troyville, and Coles Creek-like ceramics, it was concluded that these ceramic types were also co-existent (Jelks 1961:47-55).

The Jonas Short Mound (situated in San Augustine County on the Angelina River), and its close cousin the Coral Snake Mound (in Sabine Parish, Louisiana on the lower Sabine River), are also two very interesting Woodland Period sites which reinforce the close relationship between the Fourche Maline Culture and the Alto focus. Both the Jonas Short and Coral Snake sites consist of single conical-shaped mounds with human cremations. Within each mound were a series of caches which contained Middle Woodland Period artifacts, including boatstones, copper earspools, gorgets and bracelets, perforated animal teeth, quartz crystals, and large chipped stone blades (McClurkan et al. 1966, McClurkan et al. 1980). Within the mound fill at both sites were Marksville or Coles Creek-like ceramics mixed with what appeared to be Alto focus ceramics; arguably, however, some of the sherds may not be typical Alto focus types. No arrow points were associated with the mounds at either site (McClurkan et al. 1966, 1980), and radiocarbon dates from the Coral Snake site suggested that the mound there was built sometime during the 4th century A.D. (McClurkan et al. 1966:25). At both sites, it was argued that the Caddo ceramics were not mixed in with the earlier mound materials (McClurkan et al. 1966:25-26; McClurkan et al. 1980:192-195).

Upon examining the Marksville pottery descriptions from the Coral Snake site, it was noted that the sherds were tempered with crushed bone (McClurkan et al. 1966:14). Therefore, I conclude that the Marksville Stamped and Churupa Punctated sherds from Coral Snake were not trade wares from the Lower Mississippi Valley but were instead made locally, probably by Fourche Maline potters. To reinforce the notion that a resident 
population built both mounds at Coral Snake and Jonas Short, there is the fact that the pastes of the Alto focus ceramics from both sites were also bone-tempered, and were made from virtually the same paste as the so-called Lower Mississippi Valley pottery.

The inescapable conclusion is that the Alto Focus ceramics recovered from the Resch, Snipe, Jonas Short, and Coral Snake sites were made by Fourche Maline potters who also produced the Woodland Period Lower Mississippi Valley style ceramics. If Alto focus ceramics were made by Fourche Maline potters at least as early as the Middle Woodland Period, then it must be concluded that much of the Alto Focus is Fourche Maline.

If we look at other Early Ceramic Period sites in Texas, such as Manton Miller and a number of sites along the South Sulphur River within the Cooper Lake project area, we discover that there is quite a bit of Alto focus ceramics at these sites as well. In the past, conventional wisdom has assured many Texas archaeologists that Alto focus ceramics recovered from these sites were always derived from later Caddo occupations (Hyatt et al. 1974; Hyatt and Doehner 1975; Doehner and Larson 1978; Doehner et al. 1978). However, based on the archaeological evidence at the Snipe, Resch, Jonas Short, and Coral Snake sites, this cannot always be assumed to be the case (Jelks 1961; Webb et al. 1969:89-90; McClurkan et al. 1966:25-26; McClurkan et al. 1980:192-195.

\section{The Fourche Maline Culture and its Relationship to the Origin of the Caddo Culture}

At the Crenshaw site, considered to be the largest Fourche Maline settlement in the Caddo Area, located on the Great Bend of the Red River in southwest Arkansas, there appears to be evidence of a shift from a late Fourche Maline occupation to an incipient Caddo Culture occupation, and the critical detector of this shift is a change in ceramic style (Schambach 1982:171). Basically, Fourche Maline ceramics are primarily plain wares. However, from early on, a few vessels were decorated around the exterior rim portion (Bell and Baerreis 1951; Bell 1980; Schambach 1982). At the same time, occasional Lower Mississippi Valley horizon style decorative patterns (reflected in Marksville, Troyville, and Coles Creek-like ceramics) were also incorporated into the Fourche Maline ceramic ensemble. Like the Fourche Maline Culture, decorations around the exterior rim portion of vessels was the common decorative mode used in the Lower Valley.

It has been argued that some time after A.D. 850 , some of the vessels at the Crenshaw site began to be decorated on the body as well as around the rim portion (Schambach 1982:171, 1989 personal communication). This shift from rim decorations to both rim and body decorations on a single vessel was the beginning of the classic Caddo ceramic lief motif, which consisted of a dual decorative pattern (rim and body) around the vessel (Schambach 1982:171, 1989 personal communication). For example, the rim portion of an Early Caddo vessel would be decorated with incised horizontal lines, while the body portion of the vessel would be decorated with incised curvilinear lines (interlocking scrolls, etc.).

One of the first ceramic types which appeared to bridge the Fourche Maline-Caddo transition was a Woodland Period, Lower Mississippi Valley type made from a Fourche Maline paste, called French Fork Incised (Schambach 1982:170-172). Typical French Fork Incised pottery consists of curvilinear incised designs (interlocking scrolls or volutes, many of which are filled with small punctations) which were executed around the rim portion of the vessel (Phillips 1970:83-86, 202-204). At the Crenshaw site, towards the end of the first millenium A.D., the French Fork Incised decortaive pattern shifted down to the body portion of the vessel and was fused with a Coles Creek horizontal 
incised line decoration around the rim (Schambach 1982:171, 1989 personal communication). This in essence was the first true Caddo ceramic type. During and afterwards in the Caddo Culture Area, this dual decorative pattern was repeated with a combination of decorative techniques such as incising, engraving, punctating, finger impressing, applique, etc., coupled with new decorative patterns which was manifested fully in all of the true Caddo foci, complexes, and phases after A.D. 1000.

What is interesting is that French Fork Incised (particularly the Larkin variety) of the Fourche Maline variant (rim decorations only) and Caddo variants (rim and body decorations) is virtually identical to the Alto focus type called Crockett Curvilinear Incised. Upon examining illustrations and photographs of this type, it is overwhelmingly apparent that many of the vessels are of the Woodland Period Fourche Maline variant (see Newell and Krieger 1949:101, 103; Suhm and Jelks 1962:32-34). On the other hand, there are true Caddo variants of Crockett Curvilinear Incised mixed with the same series of illustrations and photographs. It is interesting that many of these examples are from Crenshaw as well as the George C. Davis sites (Suhm and Jelks 1962:32-34).

Pennington Punctate-Incised is another Alto focus ceramic type which appears to span the transition between the Fourche Maline and Caddo Cultures. Both rim and dual decorated forms exist; however, it appears through the illustrations and photographs (Newell and Krieger 1949:103-105; Suhm and Jelks 1962:122) that rim decorated forms of the Fourche Maline variant were predominant. In fact, at the George C. Davis site, Pennington Punctate-Incised was believed to have begun at an earlier point in time than Crockett Curvilinear Incised (Newell and Krieger 1949:98). Pennington PunctateIncised was also recognized as being very similar to related Woodland Period Lower Mississippi Valley types, and stylistically very close to Avoyelles Punctated variety Avoyelles (Newell and Krieger 1949:98; Phillips 1970:41-43, 181).

Other Alto focus ceramic types, such as Davis Incised, are essentially the same (except for the lip line) as the Fourche Maline Coles Creek variants found at the Crenshaw site. All of the Coles Creek variants in both the Caddo Area and the Lower Mississippi Valley are decorated only around the rim, and date to the Woodland Period. Many of the engraved Alto focus types such as Hickory Engraved and Holly Engraved have decorations which are restricted to the rim area; however, there are also dual decorated Caddo variants of both of these engraved types.

If we can define the beginning of the Caddo Culture ceramically with the introduction of the dual decorated styles, then it is very probable that the Alto focus is transitional in nature, and that it originates within the Fourche Maline Culture, probably as far back as the Middle Woodland Period. If this is an acceptable premise, then there can be no question that a very vibrant late Fourche Maline Culture existed in Northeast Texas, and the antecedence of this culture was probably also native to Texas as well.

The late Fourche Maline Alto focus occupation at the George C. Davis site would have been contemporary with the Woodland Period Coles Creek Culture of the Lower Mississippi Valley (Brain 1978:338). This is based on a series of calibrated radiocarbon dates which olaces the beninning of the post-sandy paste ceramic occupation at the Davis site after A... 30 (Story and Valastro 1977). It is interesting to speculate that the dual decorative ceramic pattern, which initiates, or at least signifies the beginning of the Caddo Culture, may have started at the Davis site as early as it appeared at the Crenshaw site, or even earlier. 


\section{Conclusion: The Placement of the Sanders and Alto Foci in Relation to the Fourche Maline Culture in Texas}

As was pointed out at the beginning of the paper, when the Fourche Maline focus was first defined in eastern Oklahoma, it was recognized that the ceramics from this focus were very similar to ceramics from the Sanders focus across the Red River in northeast Texas (Krieger 1947:202; Bell 1980:86). Basically, both foci were composed of a high frequency of plain grog and bone tempered ceramics. Indeed, in recent ceramic comparisons, it has been confirmed that sherds found in Texas typed as Sanders Plain are typologically identical to sherds typed as Williams Plain found in Oklahoma (Brown 1971:167-169).

The few vessels which were decorated in both foci were practically identical in design, and this was especially apparent in what was called Canton Incised in the Sanders focus and Williams Plain Decorated in the Fourche Maline focus (Krieger 1947; Bell 1953:327; Proctor 1957:75; Duffield 1961:89). Both ceramic types were decorated only around the rim with diagonal or cross-hatched incised designs. Many of the CantonIncised vessels were flower-pot shaped with flat bases, which in form could not be distinguished from Williams Plain type vessels found at Fourche Maline sites. Indeed, Canton Incised vessels of the Sanders focus have been found repeatedly at Early Ceramic Period sites in Texas such as the Resch, Yarbrough, and Limerick sites (Webb et al. 1969:28; Johnson 1962:202-203; Duffield 1961:89-90).

Like Alto focus ceramics, conventional wisdom has dictated to most archaeologists working in Texas that these vessels must date to Caddo times. Interestingly, in the Cooper Lake project area, both Alto focus ceramics (Pennington Punctate-Incised and Crockett Curvilinear Incised) and Canton Incised ceramics co-occur with overwhelming proportions of sherds which have been classified as Sanders Plain, but are in reality probably Williams Plain. Technically, many of the archaeological components containing both Alto and Sanders focus pottery in the Cooper Lake area have been termed "Gibson Aspect" or Early Caddoan occupations (Hyatt et al. 1974; Hyatt and Doehner 1975; Doehner and Larson 1978; Doehner et al. 1978). The only problem is that most of these components probably date to the Woodland Period.

Had it not been for the late occupation at the Sanders site, which appeared to be sometime after A.D. 1000, Krieger probably would have affiliated the Sanders focus with what was beginning to be called the Fourche Maline focus. Had Krieger found the Sanders focus in an earlier context than he did at the Sanders site, Frank Schambach probably would have called the Fourche Maline Culture the Sanders Culture and everyone in Texas would have been satisfied.

What seems to be apparent though is that the Fourche Maline Culture did persist in parts of eastern Oklahoma and Northeast Texas well into Caddo times. It appears that in Oklahoma, Fourche Maline occupations were contemporary with later Caddo-loke occupations dating to the Spiro focus (Proctor 1957:90; Bell 1980:98). In fact, there may have been some hostilities between these groups (Wyckoff 1989, personal communication). The presence of shell tempered ceramics at such sites as the Sam site in eastern Oklahoma also attests to the possibility that some Fourche Maline occupations lasted into the "Fulton Aspect" or Late Caddoan times (Proctor 1957; Bell 1980:98). This may also be the case for such sites as Scott and Wann, and other isolated Fourche Maline sites, in the Ouachita Mountains. 
Unlike the Oklahoma Fourche Maline in the northern Ouachitas, the resident Fourche Maline populations living at the Sanders site (including other Sanders focus-like populations living on either side of the Red River) appear to have chosen to assimilate themselves with the Caddo cultures farther to the east, especially with the Caddos living along the Red River, and perhaps with Spiro. This would explain the Caddo-like interments located within Mound $B$, and the proliferation of Southern Cult items (particularly the carved conch shell gorgets) found in association with the burials at the Sanders site. Nevertheless, it is clear that the Sanders focus people chose to retain their Fourche Maline ceramic styles (but perhaps incorporated Caddo forms such as carinated bowls and bottles) which when decorated were done only along the rim portions. To my knowledge, no dual body and rim Caddo-like decorations have ever been affiliated with any Sanders focus type pottery. Dual decorated pottery occurring at Sanders focus sites have always been connected with Caddo trade wares.

In the end, I believe that the Fourche Maline Culture is a viable archaeological entity which primarily describes a language-bound, ecologically and economically diverse, culture which was residing in the Trans-Mississippi South. This bio-geographic region includes parts of Arkansas, Louisiana, Oklahoma, as well as parts of Texas--primarily Northeast Texas, east and north of the Trinity River. As archaeologists, we can trace the presence of the Fourche Maline Culture through the remains of its material culture, namely the ceramics which are found throughout the Caddo Area.

At the tail end of the Fourche Maline Culture, it gives way to a more elaborate manifestation known as the Caddo Culture. The Caddo Culture does not override the Fourche Maline Culture, but emerges from it. As a result of this evolutionary process, we see the precocious developments of the Caddo Culture within the later part of the Fourche Maline Culture, which occurs sometime during the latter part of the Woodland Period. I believe that the incipient developments of the Caddo Culture can be seen in Texas during the Alto focus. Essentially, the Alto focus is a Late Fourche Maline manifestation which reaches full fruition during Early Caddo times.

The Sanders focus of Texas also evolves out of the Fourche Maline Culture, but it is autonomous from the Alto focus. The Sanders focus retained much of its traditional Fourche Maline material culture, namely the ceramics, and interacted with true Caddo cultures after the onset of the Alto focus. However, unlike the Alto focus, people of the Sanders focus never completely bought into the Caddo culture milieu, and as a result, they form a distinct Western Caddo manifestation which was unique to the Caddo Area.

To sum, both the Alto and Sanders foci can be categorized as late Fourche Maline cultural manifestations. However, once true Caddo elements enter either one of these foci, they should probably be categorized as transitional Caddo, or what I believe to be more of an appropriate term, epi-Fourche Maline.

\section{Acknowledgements}

I would like to thank Frank Schambach for his open and generous use of his collections, primarily the ceramics from the Crenshaw Site and Phillips' original type collection from the Yazoo River Basin. The discussions generated from these collections was the basis for this paper. I would also like to thank Dee Ann Story for her cooperation and insightful references on Early Ceramic sites in Texas, which essentially formed the data base for the paper. Last, I would like to thank Randy Moir for giving me the time and support for writing this paper. This paper was originally presented at the 1990 Caddo Conference held at Natchitoches, Louisiana. 


\section{References Cited}

Aten, Lawrence E.

1983 Indians of the Upper Texas Coast. Academic Press, New York.

Bell, Robert E.

1948 Recent archaeological research in Oklahoma. Bulletin of the Texas Archeological and Paleontological Society 19:148-154.

1949 Recent archaeological research in Oklahoma. The Chronicies of Oklahoma 27 (3):303-312.

1953 The Scott Site, LeFlore County, Oklahoma. American Antiquity $18(4): 314-331$.

1980 Fourche Maline: An Archaeological Manifestation in Eastern Oklahoma. In Caddo and Poverty Point Archaeology: Essays in Honor of Clarence Hungerford Webb. Louisiana Archaeology No. 6, pp. 83-125.

Bell, Robert E. and David A. Baerreis

1951 A Survey of Oklahoma Archaeology. Bulletin of the Texas Archeological and Paleontological Society 22:7-100.

Brain, Jeffrey $P$.

1978 Late Prehistoric Settlement Patterning in the Yazoo Basin and Natchez Bluffs regions of the Lower Mississippi Valley. In Mississippian Settlement Patterns, edited by Bruce D. Smith. Academic Press, New York.

Brown, James A.

1971 Spiro Studies, Pottery Vessels, Volume 3. First Part of the Third Annual Report of Caddoan Archaeology-Spiro Focus Research. University of Oklahoma Research Institute, Norman.

Childe, V. Gordon

1942 What Happened in History. Routledge and Kegan Paul, London.

1952 New Light on the Most Ancient East. Routledge and Kegan Paul, London.

Davis, E. Mott (editor)

1961 Proceedings of the Fourth Conference on Caddoan Archeology. Bulletin of the Texas Archeological Society 30:2-31.

Dickinson, Samuel D.

1936 Ceramic relationships of the pre-Caddo pottery from the Crenshaw site.

Bulletin of the Texas Archeological and Paleontological Society 8:56-69.

Doehner, Karen and Richard E. Larson

1978 Archaeological Research at the Proposed Cooper Lake, Northeast Texas 1974-1975. Archaeology Research Program, Southern Methodist University, Research Report 108. Dallas. 
Doehner, Karen, Duane Peter, and S. Alan Skinner

1978 Evaluation of the Archaeology at the Proposed Cooper Lake. Archaeology Research Program, Southern Methodist University, Research Report 114. Dallas.

Duffield, Lathel F.

1961 The Limerick Site at Iron Bridge Reservoir, Rains County, Texas. Bulletin of the Texas Archeological Society 30:51-117.

Ford, James A.

1951 Greenhouse: a Troyville-Coles Creek Period Site in Avoyelles

Parish, Louisiana. American Museum of Natural History, Anthropological Papers 44(part 1). New York.

Fulton, Robert and Clarence Webb

1953 The Bellevue Mound: A pre-Caddoan site in Bossier Parish, Louisiana.

Bulletin of the Texas Archeological Society 24:18-42.

Hoffman, Michael P.

1970 Archeological and historical assessment of the Red River Basin in Arkansas. In Archeological and Historical Resources of the Red River Basin, edited by Hester A. Davis, pp. 137-194. Arkansas Archeological Survey, Research Series No. 1. Fayetteville.

1971 A Partial Archeological Sequence for the Little River Region, Arkansas. Ph.D. dissertation, Harvard University.

Hyatt, Robert D., Barbara H. Butler, and Herbert P. Mosca III

1974 Archaeological Research, Cooper Lake 1970-1972. Southern Methodist University, Contributions in Anthropology No. 12. Dallas.

Hyatt, Robert D. and Karen Doehner

1975 Archaeological Research at Cooper Lake, Northeast Texas, 1973. Southern Methodist University, Contributions in Anthropology No. 15. Dallas.

Jelks, Edward B.

1961 Excavations at Texarkana Reservoir, Sulphur River, Texas. Bureau of American Ethnology, Bulletin 179, River Basin Surveys Papers No. 21:1-78. Washington, D.C.

Johnson, Leroy, Jr.

1962 The Yarbrough and Miller Sites of Northeastern Texas, with a Preliminary Definition of the La Harpe Aspect. Bulletin of the Texas Archeological Society $32: 140-284$.

Krieger, Alex D.

1947 The first symposium on the Caddoan archaeological area. American Antiquity $12: 198-207$.

McClurkan, Burney B., William T. Field, and J. Ned Woodall

1966 Excavations in Toldeo Bend Reservoir, 1964-65. Texas Archeological Salvage Project, Papers No. 8. Austin. 
McClurkan, Burney B., Edward B. Jelks, and Harold P. Jensen

1980 Jonas Short and Coral Snake Mounds: A Comparison. Caddo and Poverty Point

Archaeology: Essays in Honor of Clarence Hungerford Webb, Bulletin of the Louisiana Archaeological Society, No. 6, pp. 173-206.

Newell, H. Perry and Alex D. Krieger

1949 The George C. Davis Site, Cherokee County, Texas. Society for

American Archaeology, Memoirs No. 5. Menesha, Wisconsin.

Newkumet, Phil J.

1940a Preliminary report on excavations of the Williams Mound, LeFlore County,

Oklahoma. The Oklahoma Prehistorian 3(2):2-6.

1940b Excavation of "Black Mound" reveals ornate "Hair Pins". The Oklahoma Prehistorian 3(2):8-9.

Perttula, Timothy $\mathrm{K}$.

1980 Caddoan Prehistory: Some relationships to Lower Mississippi Valley

prehistory. Southeastern Archaeological Conference, Bulletin 21:119-123.

Phillips, Philip

1970 Archaeological Survey in the Lower Yazoo Basin, Mississippi, 1949-1955. Papers of the Peabody Museum of Archaeology and Ethnology, Harvard University, Volume 60. Peabody Museum, Cambridge.

Proctor, Charles

1957 The Sam Site, Lf-28, of LeFlore County. Bulletin of the Oklahoma Anthropological Society 5:45-91.

Schambach, Frank F.

1970 Pre-Caddoan Cultures in the Trans-Mississippi South: A beginning sequence. Ph.D. dissertation, Harvard University, Cambridge.

1982 An Outline of Fourche Maline Culture in Southwest Arkansas. In Arkansas Archeology in Review, edited by Neal Trubowitz and Marvin D. Jeter, pp. 132-197. Arkansas Archeological Survey, Research Seriess 15. Fayetteville.

Smith, Bruce D. (editor)

1978 Mississippian Settlement Patterns. Academic Press, New York.

Story, Dee Ann

1981 An Overview of the Archaeology of East Texas. Plains Anthropologist 26(92):139-156.

1985 Adaptive Strategies of Archaic Cultures of the West Gulf Coastal Plain. In Prehistoric Food Production in North America, edited by Richard I. Ford, pp. 19-56. Anthropological Papers, Museum of Anthropology, University of Michigan, No. 75. Ann Arbor.

1990 Cultural History of the Native Americans. In The Archeology and Bioarcheology of the Gulf Coastal Plain, by D.A. Story et al., pp. 163-366. Arkansas Archeological Survey, Research Series No. 38. Fayetteville. 
Story, Dee Ann and Sal Valastro, Jr.

1977 Radiocarbon Dating and the George C. Davis Site, Texas. Journal of Field Archaeology 4:64-89.

Suhm, Dee Ann and Edward B. Jelks 1962 Handbook of Texas Archeology: Type Descriptions. Texas Archeological Society and the Texas Memorial Museum, Austin.

Swanton, John R.

1946 The Indian Tribes of North America. Smithsonian Institution, Bureau of American Ethnology, Bulletin 145. Washington, D.C.

Tunnell, Curtis D.

1961 Evidence of a Late Archaic Horizon at Three Sites in the McGee Bend Reservoir, San Augustine County, Texas. Bulletin of the Texas Archeological Society 30:123-159.

Webb, Clarence H. and Hiram F. Gregory

1978 The Caddo Indians of Louisiana. Department of Culture, Recreation and

Tourism, Louisiana Archaeological Survey and Antiquities Commission, Anthropological

Study 2. Baton Rouge.

Webb, Clarence H. and Ralph R. McKinney

1975 Mounds Plantation (16CD12), Caddo Parish, Louisiana. Louisiana Archaeology 2:39-127.

Webb, Clarence H., Forrest H. Murphey, Wesley G. Ellis, and Roland Green 1969 The Resch Site, 41HS16, Harrison County, Texas. Bulletin of the Texas

Archeological Society 40:3-106.

Wood, W. Raymond

1963a A preliminary report on the 1962 excavations at the Crenshaw site, 3MI6. In

Arkansas Archeology 1962, edited by Charles R. McGimsey III, pp. 1-14. Fayetteville.

1963b The Poole site: components of the Fourche Maline and Mid-Ouachita foci in Garland County, Arkansas. MS on file, University of Arkansas Museum, Fayetteville.

Wyckoff, Don G.

1966 The Hughes, Lamas Branch, and Callahan sites, McCurtain County, southeast Oklahoma. Oklahoma River Basin Survey Project, Archaeological Site Report 4. Norman.

1970 Archaeological and Historical Assessment of the Red River Basin in Oklahoma. In Archeological and Historical Resources of the Red River Basin, edited by Hester A. Davis, pp. 69-134. Arkansas Archeological Survey, Research Series No. 1. Fayetteville. 